\title{
Influence of particle size and density on mean retention time in the rumen of dairy cows
}

\author{
F. Dufreneix, ${ }^{1,2}$ P. Faverdin, ${ }^{1}$ and J.-L. Peyraud ${ }^{1 *}$ \\ ${ }^{1}$ Physiologie, Environnement et Génétique de l'Animal et des Systèmes d'Elevage, Agrocampus Ouest, INRA, F-35590 Saint-Gilles, France \\ ${ }^{2}$ Agrial, 4 rue des Roquemonts, F-14000 Caen, France
}

\section{ABSTRACT}

Increasing rumen-undegraded protein is one challenge of ruminant nutrition to both meet protein requirements of animals and reduce nitrogen excretion in the environment by increasing nitrogen efficiency. Industrial processes using heat or tanning to reduce rumen protein degradation have certain limitations, such as difficulty in balancing low ruminal degradation and high intestinal digestibility. Reducing the mean retention time (MRT) in the rumen by varying the size and density of particles may be another promising way to increase the rumen-undegraded protein proportion of concentrate feeds and improve the effectiveness of industrial processes. Spherical plastic particles of 3 mean diameter sizes $(1,2$, and $3 \mathrm{~mm})$ and 4 densities $(0.9$, $1.1,1.3$, and 1.5) were used to study the combined effect of size and density on the MRT of particles without interactions with microbial fermentations. Dynamics of fecal excretion of particles were monitored over $106 \mathrm{~h}$ (17 sampling times) in a Latin square experiment with 4 lactating cows. Cumulative particle excretion curves were fitted to a double exponential model to calculate total MRT in the digestive tract (TMRT), MRT in 2 compartments (MRT1 and MRT2), and retention time in the intestines' tubular section (TT). Differences in density had a quadratic effect, with densities of 1.1 and 1.3 yielding lower TMRT (29.5 and $31.2 \mathrm{~h}$, respectively) than the densities of 0.9 and 1.5 (TMRT $=64.0$ and $51.2 \mathrm{~h}$, respectively). Similar responses were observed for MRT1, which was assumed to be the ruminal MRT for densities 1.1 and 1.3 (8.9 and $10.5 \mathrm{~h}$, respectively) compared with densities 0.9 and 1.5 (39.6 and $22.6 \mathrm{~h}$, respectively). Differences in diameter had a linear effect on TMRT (12.9 h longer for $3 \mathrm{~mm}$ than for $1 \mathrm{~mm}$ ) and on TT. A combined effect of size and density was

Received October 31, 2018.

Accepted December 28, 2018.

*Corresponding author: jean-louis.peyraud@inra.fr observed and particle size had no effect on TMRT when density was 1.1 to 1.3 ; however, outside this range, an increase in particle diameter increased TMRT. Consequently, a density of 1.2 to 1.3 is optimal for the escape of particles. As smaller particles of concentrates lose functional specific gravity more rapidly than larger particles due to their higher fermentation rate, our results, obtained with plastic particles, suggest that a diameter slightly greater than $3 \mathrm{~mm}$ seems a compromise to delay the start of fermentation and allow for rapid passage through the reticulo-omasal orifice.

Key words: mean retention time, rumen, plastic particle, dairy cow

\section{INTRODUCTION}

Increasing the proportion of RUP in feed, especially in protein-rich supplements such as oil seed meals or legume grain, is one challenge for the nutrition of highproducing dairy cows to increase protein-use efficiency and reduce nitrogen excretion in the environment by increasing nitrogen efficiency. Digestion of concentrate feeds in the rumen depends on their degradation rate and retention time.

To increase the proportion of RUP, feed manufacturers developed processes to reduce the degradation rate of concentrates. The main processes are heat treatments (Whitelaw et al., 1961; Sherrod and Tillman, 1964; Krizsan et al., 2017) and tanning with formaldehyde (Vérité et al., 1977); however, heat treatment can reduce intestinal digestibility or become ineffective at protecting feeds when industrial processes are not well monitored (Broderick et al., 1991). Formaldehyde tanning is highly effective (Barry, 1976) in reducing the ruminal degradability of protein and preserving high intestinal digestibility; however, most feed manufacturers have stopped using it due to lack of social acceptance and carcinogenic risks for feed factory employees. New processes based on plant-based tanning or essential oils were tested, but they have variable efficacy in vivo (Min et al., 2003; Waghorn, 2008; Bayourthe and AliHaimoud-Lekhal, 2014). 
Manipulating retention time in the rumen has not received much attention until recently. However, decreasing ruminal retention time can improve the efficiency of protection processes by increasing the probability that particles escape the rumen before extensive microbial degradation. The combination of short retention time in the rumen and short-term protection could result in high escape protein of concentrates. Physical characteristics, such as size and functional specific gravity, are known to influence the retention time of concentrates in the rumen (Lechner-Doll et al., 1991). Functional specific gravity corresponds to particle density associated with volumes occupied by liquids and gases, which evolve during hydration and digestion (Sutherland, 1986; Wattiaux et al., 1993).

Studying the influence of particles' physical characteristics on their retention time requires using inert particles because their size and density can be strictly controlled and they do not interact with microbial fermentation. Several studies using this approach have investigated the influence of physical characteristics, such as size and density, on the mean retention time (MRT) of plastic particles (King and Moore, 1957; Campling and Freer, 1962; Welch and Smith, 1978; DesBordes and Welch, 1984; Ehle and Stern, 1986; Murphy et al., 1989; Kaske and Engelhardt, 1990; Prigge et al., 1990; Clauss et al., 2011) in the entire digestive tract and in the rumen. The general observations of these studies are that the MRT of particles negatively correlates with particle size and that a density of 1.1 to 1.4 minimizes MRT in the rumen. These results, however, come from studies that used low-producing animals (dry cows, steers, or sheep), whereas it is well established that both ruminal and total MRT of particles decrease as intake increases (Verite et al., 1987); therefore, highproducing dairy cows may have different responses to particle size and density. Most of these studies aimed to estimate the MRT of forage particles, so the size tested (length mean $6.5 \mathrm{~mm}$ ) was larger than the size of concentrate particles. Only Murphy et al. (1989) examined the influence of size and density of plastic particles in the range close to concentrates; however, the experimental diet of their study (95\% of rice straw) could not be applied to cover the high requirements of lactating cows, as rice straw is a low-energy, low-protein, and low-digestible feed.

We explored the combined effect of the size and density of plastic particles on the retention time in different parts of the gastrointestinal tract of lactating cows and tested the hypothesis that a certain size and density combination would yield the lowest MRT for particles in the rumen. The range of variation in size and density was chosen to encompass the values generally observed for concentrates.

\section{MATERIALS AND METHODS}

\section{Principle of the Measurements}

Four diameter sizes $(0.5,1,2$, and $3 \mathrm{~mm})$ and 4 densities $(0.9,1.1,1.3$, and 1.5$)$ of plastic particles, resulting in 16 size $\times$ density combinations, were tested with 4 lactating cows in a Latin square design during four 1 -wk periods. Particles were pulse-dosed in the rumen of each cow at each period. After dosing, excretion of particles was monitored by collecting all fecal material. The number of plastic particles was determined using a method to separate plastic particles from feces (adapted from DesBordes and Welch, 1984) and an innovative image analysis, based on a color-separation of particles followed by an ImageJ counting (ImageJ $1.47 \mathrm{v}$ software; US National Institutes of Health, Bethesda, MD). Excretion dynamics were adjusted to a double exponential model (Grovum and Williams, 1973) to calculate total mean retention time (TMRT) in the gastrointestinal tract and the 3 compartments identified by the model: 2 mixing compartments, the first associated with the rumen, and the intestines' tubular section. Mean retention time for the 3 sizes (1, 2, and $3 \mathrm{~mm})$ and 4 densities $(0.9,1.1,1.3$, and 1.5) of plastic particles in the entire digestive tract and its 3 compartments is presented in Appendix Table A1.

\section{Animals, Diets, and Experimental Design}

Four multiparous cows [mean of $727 \mathrm{~kg}$ of BW $(\mathrm{SD}=$ $30.5) ; 29.9 \mathrm{~kg}$ of milk/d $(\mathrm{SD}=6.8) ; 21.9 \mathrm{~kg}$ of $\mathrm{DMI} / \mathrm{d}$ $(\mathrm{SD}=2.5)$ ] were used in a Latin square experiment on the experimental farm of Méjusseaume (Le Rheu, France). All cows were fitted with large (i.e., 123-mm diameter) rumen cannulas at least 1 yr before the beginning of the experiment and were confirmed pregnant before the experiment to avoid differences in DMI due to estrus. The cows were housed in individual stalls equipped with automatic troughs and were milked twice a day at 0700 and $1700 \mathrm{~h}$. The experiment lasted $54 \mathrm{~d}$, including an adaptation period of $28 \mathrm{~d}$. The cows were fed ad libitum during the first $14 \mathrm{~d}$ to determine individual ad libitum DMI. For the following $14 \mathrm{~d}$, cows were adapted to restricted feeding, which was set to $95 \%$ of each cow's individual DMI to ensure constant DMI during the trial. Access to the troughs was restricted to four 1-h periods (starting at 0200, 0800, 1400 , and $2000 \mathrm{~h}$ ) per day to spread DMI throughout the day. Cows had free access to water and a feed block. Meals contained maize silage, concentrates with minerals, tanned soybean meal, and chopped dehydrated alfalfa (Table 1). Procedures related to surgery, care, and use of animals for the experiment were approved by an 
Table 1. Chemical composition and nutritional values of feeds $(\mathrm{g} / \mathrm{kg}$, unless otherwise indicated)

\begin{tabular}{|c|c|c|c|c|}
\hline Characteristic & $\begin{array}{l}\text { Maize } \\
\text { silage }\end{array}$ & $\begin{array}{l}\text { Concentrate } \\
\text { with mineral }\end{array}$ & $\begin{array}{c}\text { Tanned } \\
\text { soybean meal }\end{array}$ & $\begin{array}{c}\text { Chopped } \\
\text { dehydrated alfalfa }\end{array}$ \\
\hline Amount in the $\operatorname{diet}(\%)$ & 60 & 15 & 15 & 10 \\
\hline DM & 376 & 919 & 905 & 924 \\
\hline $\mathrm{CP}$ & 66 & 102 & 506 & 189 \\
\hline NDF & 422 & 196 & 102 & 420 \\
\hline $\mathrm{ADF}$ & 239 & 79 & 61 & 299 \\
\hline Net energy $\left(\mathrm{UFL}^{2} / \mathrm{kg}\right.$ of $\left.\mathrm{DM}\right)$ & 0.91 & 0.96 & 1.2 & 0.63 \\
\hline \multicolumn{5}{|l|}{ MP } \\
\hline $\mathrm{g}$ of PDIE $/ \mathrm{kg}$ of $\mathrm{DM}^{3}$ & 63 & 91 & 248 & 95 \\
\hline $\mathrm{g}$ of PDIN/kg of $\mathrm{DM}^{4}$ & 41 & 69 & 361 & 119 \\
\hline
\end{tabular}

${ }^{1}$ Contained (in \%) 18.3 wheat, 18.3 maize, 18.3 barley, 13.2 wheat feed flour, 18.3 beet pulp, 0.9 rapeseed oil, 3 sugar cane molasses, 0.9 salt, 2 AdiSodium (Bluestar Adisseo Co., Ltd., Beijing, China), and 6.8 minerals (5.5\% P, 27\% Ca and 4\% Mg).

${ }^{2} \mathrm{UFL}=$ unité fourragère lait; amount of net energy for milk production contained in $1 \mathrm{~kg}$ of a reference barley ( $87 \%$ DM, 2,700 kcal of ME), based on the INRA feeding system (INRA, 2007).

${ }^{3} \mathrm{PDIE}=$ truly digestible $($ dietary + microbial $)$ protein when available energy decreases microbial growth.

${ }^{4} \mathrm{PDIN}=$ truly digestible $($ dietary + microbial $)$ protein when available degradable nitrogen decreases microbial growth.

animal committee of the French Ministry of Agriculture (no. 201606132002401), in accordance with European Directive 2010/63/UE.

\section{Plastic Particles}

Particles used in the experiment were a mix of polypropylene and barium sulfate (manufactured by CRITT Polymères Picardie, Verneuil-en-Halatte, France). The barium sulfate was added to the polypropylene during manufacturing at $0,21.87,37.77$, and $49.99 \%$, to obtain final densities of $0.9,1.1,1.3$, and 1.5 , respectively. Four colorants, orange, red, purple, and white, were also added to identify the 4 density treatments samples when counting particles in fecal matter for the densities $0.9,1.1,1.3$, and 1.5 , respectively. These 3 components (polypropylene, barium sulfate, and colorant) were mixed together and heated (from 120 to $190^{\circ} \mathrm{C}$ ) by a co-rotating, twin-screw extruder (Clextral, Firminy, France) before being extruded as 3-mm diameter wire. The wire was cooled in $15^{\circ} \mathrm{C}$ water then cut to $3 \mathrm{~mm}$ in length. At this stage, $2 \mathrm{~kg}$ of each density were retained for the experiment. The remaining particles were ground (Micronis, Colayrac-Saint-Cirq, France) and sieved (Agrial, La-Selle-en-Luitré, France) to obtain 3 ranges of diameters: 0.3 to $0.6,0.9$ to 1.2 , and 1.8 to 2.5 $\mathrm{mm}$, hereafter referred to as $0.5,1$, and $2 \mathrm{~mm}$, respectively. The global shape of $0.5-, 1-$, and 2-mm particles were coarse spheres.

\section{Fecal Sampling}

The TMRT within the gastrointestinal tract was determined by monitoring dynamics of particle excretion in the feces over four 1-wk periods. In each period, cows received all 4 densities of only 1 size of particle. At the beginning of each period (0800 h on Monday, d 29, 36, 43 , and 50), approximately 8,000 particles of 3 or $2 \mathrm{~mm}$ (2,000 per density), 66,000 particles of $1 \mathrm{~mm}(16,500$ per density), or 528,000 particles of $0.5 \mathrm{~mm}(132,000$ per density) were introduced into the rumen through the cannula according to the experimental design. Total fecal output was collected 17 times during the first 106 h postdosing $(6,9,12,16,20,24,28,32,36,40,48$, $54,60,72,82,96$, and $106 \mathrm{~h})$. For the sampling times from 6 to $40 \mathrm{~h}$, total fecal outputs were collected and treated. After the 40-h sampling time, a representative subsample equal to the amount of feces collected over 4 $\mathrm{h}$ was first taken. Thus, feces from the samplings at 48, $54,60,72,82,96$, and $106 \mathrm{~h}$ were weighed, thoroughly mixed, and then $50,66,66,33,40,28$, and $40 \%$ of their total weights, respectively, were collected and treated.

\section{Treatment of Fecal Samples and Photography}

After feces were collected and weighed, most fecal matter was eliminated by wet sieving under high water pressure through 7 successive sieves $(8,4,2.5,1.5,0.8$, 0.5 , and $0.2 \mathrm{~mm}$ ). Only the material on the sieve corresponding to the particle size introduced in the rumen was collected (i.e., the $2.5-\mathrm{mm}$ sieve for 3 -mm particles, the $1.5-\mathrm{mm}$ sieve for the $2-\mathrm{mm}$ particles, the $0.8-\mathrm{mm}$ sieve for the $1-\mathrm{mm}$ particles, and the 0.5 -and $0.2-\mathrm{mm}$ sieves for the $0.5-\mathrm{mm}$ particles. Collecting particles in different sieves based on their size avoided confounding particles from a given period, as a small fraction of particles (less than 10 particles of all densities per sam- 
pling) were still being excreted during the subsequent period $(6,9$, and $12 \mathrm{~h}$ after the dosing of the subsequent period). Fecal residues and plastic particles retained on the sieves were dried at $80^{\circ} \mathrm{C}$ for $48 \mathrm{~h}$ and stored at ambient temperature in aluminum containers before counting (Figure 1).

After storage, the amount of fecal residue remaining among the $3-\mathrm{mm}$ particles was small enough that it could be photographed directly. The samples were spread on a black fabric under a digital camera (Panasonic Lumix DMC-FZ30, Osaka, Japan) and photographed. The black background prevented color interference during image analysis. For the 2-, 1-, and 0.5 -mm particles, the amount of fecal residue recovered in the corresponding sieves was too large to photograph all of it directly. Thus, each sample (fecal residue + particles; mean mass of $400 \mathrm{~g}$ ) was floated in a bucket with $8 \mathrm{~L}$ of water at ambient temperature during 5 min. Two grams of Span 20 (Croda International Plc, Goole, UK) was added to decrease surface tension. The plastic particles heavier than water (densities 1.1, 1.3, and 1.5) sank to the bottom of the bucket and were recovered after removing the fraction lighter than water. This fraction, containing particles of density 0.9 , and the fecal residues were skimmed off the water surface and then floated in another bucket with $8 \mathrm{~L}$ of boiling water to heat the fecal residues overnight. The hot fecal residues sank, and the plastic particles were skimmed off the water surface. These particles were spread on the black fabric under the camera and photographed. Each image was identified by period, date, cow, and sampling time.

The method used to recover particles of different densities and remove fecal residues before image analysis was developed for this study. We considered degrading fecal residue with acid or enzymes, but the quantities to be treated were too large and the time required was too long to use this technique. Using ethanol instead of water recovered only $80 \%$ of a known quantity of particles of density 0.9 added to feces and removed only $50 \%$ of fecal residues. The water-based recovery method described (adapted from DesBordes and Welch, 1984) recovered more than $99 \%$ of particles with a density of 1.1, 1.3, and 1.5 and all sizes of particles during a pilot study in which particles were added to fecal material. The only challenge was recovering particles of density 0.9 from fecal residues. Using water only at ambient temperature also caused fecal residues to sink to the bottom of the bucket, but the process of recovering all particles of 0.9 density took more than $2 \mathrm{~d}$. Using boiling water instead shortened the process to 1 night and also recovered all of the plastic particles.

Rumination of plastic particles was also considered, as chewing can reduce the size of the particles or de- form them greatly. During the first period, ruminated particles were identified by chewing marks. Clear chewing marks were detected only on particles of 0.9 density (less than $1 \%$ of them) and only for the last 3 sampling times $(82,96$, and $106 \mathrm{~h})$. No chewing marks were detected on particles of other densities, even those $3 \mathrm{~mm}$ in size. Consequently, ruminated and nonruminated particles were not distinguished in subsequent periods.

\section{Image Analysis}

The images were first processed with Adobe Photoshop CS5 software (Adobe Inc., San Jose, CA), which separated each image by particle color into 4 images, each showing the particles of 1 color (i.e., 1 density). Next, the number of particles in each image was counted using Image J 1.47v software (US National Institutes of Health). For the sampling times between 48 and 106 $\mathrm{h}$, the same percentages used to subsample feces were used to extrapolate the number of particles excreted in the complete fecal sample. Preliminary analyses of 3 -mm particles of all densities indicated that the image analysis was sufficiently accurate $(100.5 \%, \mathrm{SD}=2.4 \%)$. However, the analysis did not accurately distinguish $0.5-\mathrm{mm}$ particles from fecal residues remaining in the samples. Consequently, only results for 1-, 2-, and 3 -mm particles are presented. Figure 1 shows a diagram of plastic particle manufacturing, the experimental design, and the recovery procedure.

\section{Model of Particle Excretion}

We used the number of particles counted at each sampling time to adjust our data to a cumulative percentage excretion curve to avoid irregularity due to defecations. The cumulative percentage is an expression of the number of particles counted compared with the number of particles introduced into the rumen at the beginning of each period. As the initial double exponential model of Grovum and Williams (1973) considers the kinetics of concentration, we integrated this initial model for considering the cumulative excretion curve according to the following equation:

$$
\begin{aligned}
\mathrm{Y}= & (\mathrm{C} 0 / \mathrm{k} 2)-([(\mathrm{C} 0 \times \mathrm{k} 1) /(\mathrm{k} 1-\mathrm{k} 2)] \times\{\exp [-\mathrm{k} 2 \\
& \times(t-\mathrm{TT})] / \mathrm{k} 2-\exp [-\mathrm{k} 1 \times(t-\mathrm{TT})] / \mathrm{k} 1\}),
\end{aligned}
$$

where $\mathrm{C} 0$ is the adjusted plastic particle number, $\mathrm{k} 1$ and $\mathrm{k} 2$ are rate constants of the 2 models' compartments, TT is the time calculated for the first appearance of plastic particles in the feces, and $t$ is the sampling time in $\mathrm{h}$ after particles were introduced in the rumen. 


\section{Particle manufacturing}

Mix of different proportions of polypropylene and barium sulfate

+1 color per density

\section{Fecal sampling}

- Four cows in a Latin square: design of four periods

One period and one cow: particles of only one size at 4 different densities

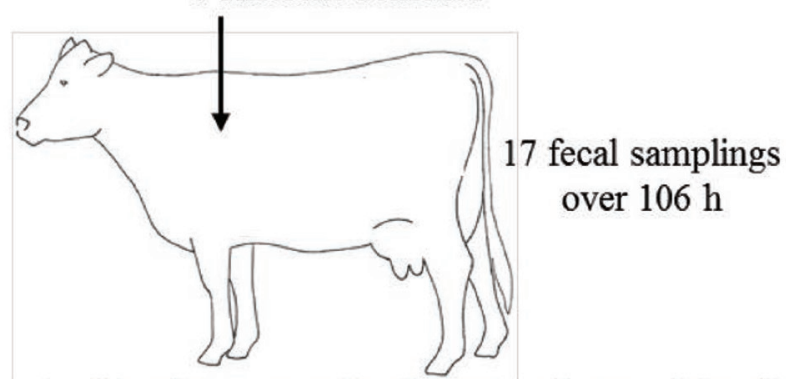

Grinding and sieving of particles of each density

\section{Density separation in water for particles size 2,1 , and $0.5 \mathrm{~mm}$}

\section{Sieving}

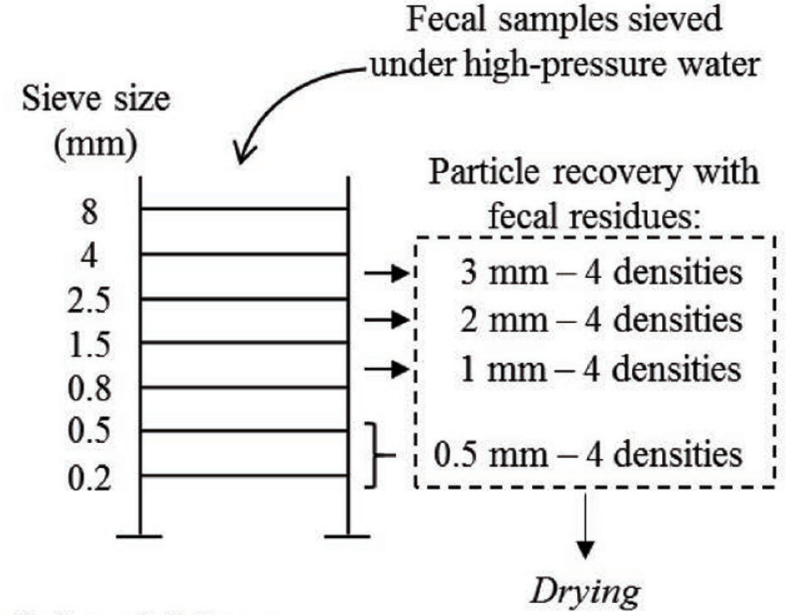

Dry fecal residues with particles of one size and 4 densities
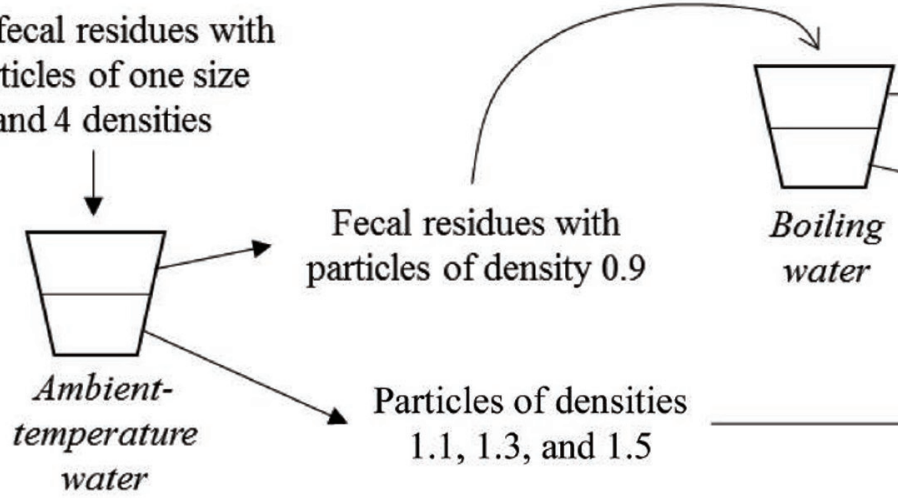

Particles of density 0.9

5. Image analysis (example for 3-mm size and 1.1, 1.3, and 1.5 densities particles with dry feces) Isolating particles of each density by their color

Counting with Image J

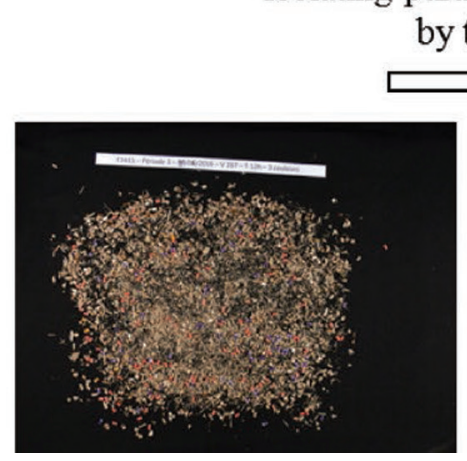
software

Figure 1. Diagram of the manufacturing of plastic particles, fecal sampling, the separation procedure, and image analysis for particles of different sizes and densities. ImageJ from US National Institutes of Health (Bethesda, MD; https://imagej.nih.gov/ij/). 
The MRT in the 2 compartments was calculated by inverting their rate-constant coefficients: $\mathbf{M R T 1}=1$ / $\mathrm{k} 1$ and MRT2 $=1 / \mathrm{k} 2$. The TMRT in the digestive tract was calculated as the sum of all 3 times: TMRT $=$ MRT1 + MRT2 + TT.

The use of Grovum and Williams' model allowed us to obtain physiological correspondence of the different compartments. Based on the study of Mambrini and Peyraud (1997), we considered MRT1 as the time required for particles to flow out of the rumen toward distal digestive compartments, $\mathrm{TT}$ as the transit time of concentrates in the intestines' tubular section, and MRT2 as the time spent in the cecum, as well as in other compartments or processes that were not clearly identified. Mambrini and Peyraud (1997) demonstrated that some of MRT2 is due to the time required to comminute large forage particles in the rumen. MRT2 is also due in part to ruminal processes such as particle mixing.

The Grovum and Williams double exponential model was also chosen based on comparison between different modes and previous work on the subject (Mambrini, 1990; Mambrini et al., 1994). Those authors compared different models with the same data set and found that models from Grovum and Williams (1973) and Ellis (1978), with a time-dependent passage rate following a gamma 2 or 3 distribution (E2 or E3), adjust best to data with the most precise estimation of parameters of the equation. We adjusted our data on these 3 models and the Grovum and Williams' one fitted best (SEM of 22, 28, and 34 respectively for Grovum and Williams, $\mathrm{E} 2$, and E3 respectively).

\section{Statistical Analyses}

Split-plot ANOVA was performed to estimate nested effects of the densities on the particle recovery rate, MRT1, MRT2, TT, and TMRT using the MIXED model procedure of SAS Enterprise Guide 6.1 (SAS Institute Inc., Cary, NC):

$$
\begin{aligned}
\mathrm{Y}_{i j k l}=\mu+ & \mathrm{P}_{i}+\mathrm{A}_{j}+\mathrm{S}_{k}+\mathrm{D}_{l}+(\mathrm{SD})_{k l} \\
& +(\mathrm{AD})_{i l}+\mathrm{e}_{i j k l},
\end{aligned}
$$

where $\mathrm{Y}_{i j k l}$ is the adjusted response variable of the model, $\mu$ is the overall mean, $\mathrm{P}_{i}$ is the effect of period $i(\mathrm{n}=4), \mathrm{A}_{j}$ is the random effect of animal $j(\mathrm{n}=4)$, $\mathrm{S}_{k}$ is the effect of particle size $k(\mathrm{n}=3), \mathrm{D}_{l}$ is the effect of particle density $l(\mathrm{n}=4),(\mathrm{SD})_{k l}$ is the effect of the interaction between size $k$ and density $l,(\mathrm{AD})_{i l}$ is the random effect of the interaction between animal $i$ and density $l$, and $\mathrm{e}_{i j k l}$ is the residual error. The MRT1 and TMRT data were analyzed after being log transformed to ensure normal distribution of their residuals.
To highlight interactions between size and density on MRT, orthogonal contrasts [linear (L) and quadratic $(\mathrm{Q})$ ], and the interactions [quadratic $\times$ linear $(\mathrm{Q} \times \mathrm{L})$, quadratic $\times$ quadratic $(\mathrm{Q} \times \mathrm{Q})$ and linear $\times$ linear $(\mathrm{L}$ $\times \mathrm{L})$ ] were tested to study the overall shape of response of size and density on different MRT in the gastrointestinal tract. Significance was declared at $P<0.05$.

\section{RESULTS}

\section{Particle Recovery Rate}

The recovery rate depended on the size and density of the particle. The lowest recovery rate $(23.1 \%$, SD $=11.7)$ was observed for particles of density 0.9. For 2- and 3-mm particles, the recovery rate was highest for those of density $1.1(90.1 \%, \mathrm{SD}=8.3)$, followed by those of density $1.3(73.6 \%, \mathrm{SD}=3.8)$ and $1.5(68.6 \%$, $\mathrm{SD}=2.9)$. For 1 -mm particles, the mean recovery rate of those with densities 1.1 to $1.5(41.4 \%, \mathrm{SD}=13.4)$ was 36 percentage points lower than that of the other 2 sizes combined (Table 2).

\section{Response of TMRT and its Compartments to Particle Size and Density}

The MRT1 averaged $39 \%$ of TMRT, but TMRT was correlated with MRT1 $($ TMRT $=1.02 \times$ MRT1 + 23.1; $\left.\mathrm{R}^{2}=0.92\right)$, with similar standard deviations for each variable (22.58 and $21.11 \mathrm{~h}$ for TMRT and MRT1, respectively), which implied that variations in MRT1 were mirrored in TMRT. Both TMRT and MRT1 had a quadratic response to density (Table 3); TMRT and MRT1 were shortest for particles of densities 1.1 and 1.3 and longest for those of density 0.9. Similar quadratic trends were observed for MRT2, which was shortest for particles of densities 1.1 and 1.3 and longest for those of density 1.5. Particle density had no influence on TT.

Increasing particle size linearly increased TMRT and TT. As particle size increased from 1 to $3 \mathrm{~mm}$, TMRT and TT increased linearly by 13.9 and $1.5 \mathrm{~h}$, respectively. Unlike density, particle size had no significant effect on MRT1 and MRT2.

Table 2. Percentage of plastic particles recovered ${ }^{1}$ for each combination of size and density of particles

\begin{tabular}{lrcc}
\hline & \multicolumn{3}{c}{ Size $(\mathrm{mm})$} \\
\cline { 2 - 4 } Density & \multicolumn{1}{c}{1} & 2 & 3 \\
\hline 0.9 & 9.3 & 37.5 & 22.5 \\
1.1 & 26.0 & 98.5 & 81.8 \\
1.3 & 48.0 & 69.8 & 77.3 \\
1.5 & 50.2 & 65.9 & 71.3 \\
\hline
\end{tabular}

${ }^{1}$ Particles recovered over a period of $106 \mathrm{~h}$. 


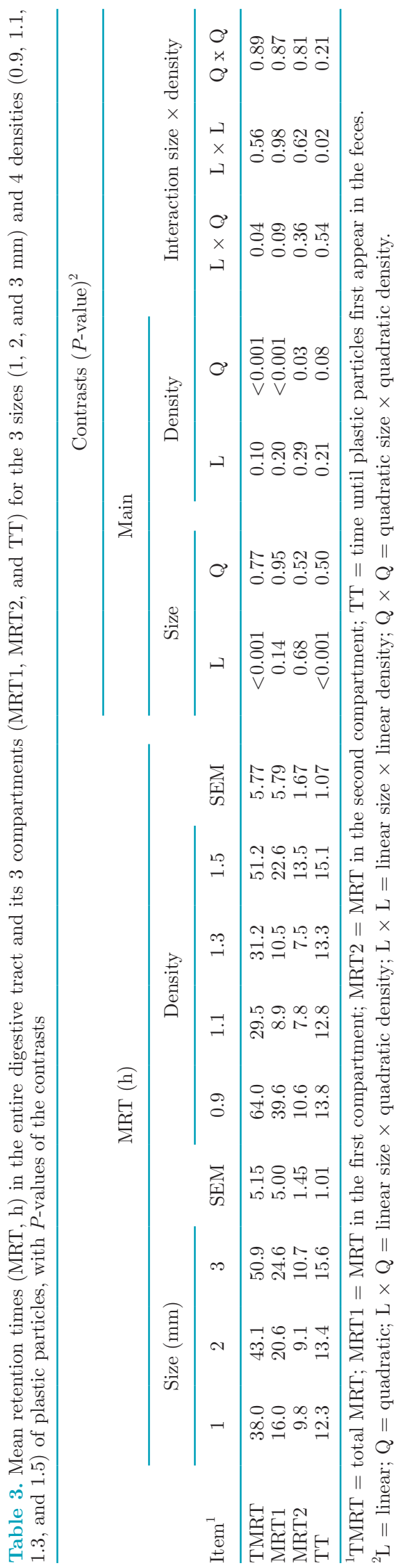

\section{Effect of Interaction between Size and Density on TT and TMRT}

The increase in TMRT as particle size increased was greater for densities 0.9 and 1.5 than for densities 1.1 and 1.3. The effect of particle density on TMRT was greatest for 3-mm particles and much smaller for 1-mm particles (quadratic $\times$ linear interaction, $P<0.04$; Figure 2). At densities of 0.9 and 1.5, 3-mm particles had a mean MRT 31 and $17.5 \mathrm{~h}$ longer, respectively, than those of 1-mm particles. No difference was observed for densities of 1.1 and 1.3, indicating that particle size had no effect on TMRT for this range of density.

The incremental increase in TT with particle size was even greater as particle density increased (linear density $\times$ linear size interaction, $P<0.02$; Figure 3 ). The slope of the relation between $\mathrm{TT}$ and size increased by $0.4,0.9,1.9$, and $3.5 \mathrm{~h} / \mathrm{mm}$ of diameter for densities $0.9,1.1,1.3$, and 1.5 , respectively. The denser and larger the particles were, the longer the TT.

\section{DISCUSSION}

\section{Fecal Recovery of Plastic Particles and Reliability of the Method}

Recovery rates of particles in our study were consistent with those of other studies (King and Moore, 1957; DesBordes and Welch, 1984; Ehle and Stern, 1986; Murphy et al., 1989). Those studies' highest recovery rates for densities 1.0 to 1.5 (70.6\%, mean of the 4 studies; Figure 4) were similar to our recovery rates for 2 - and

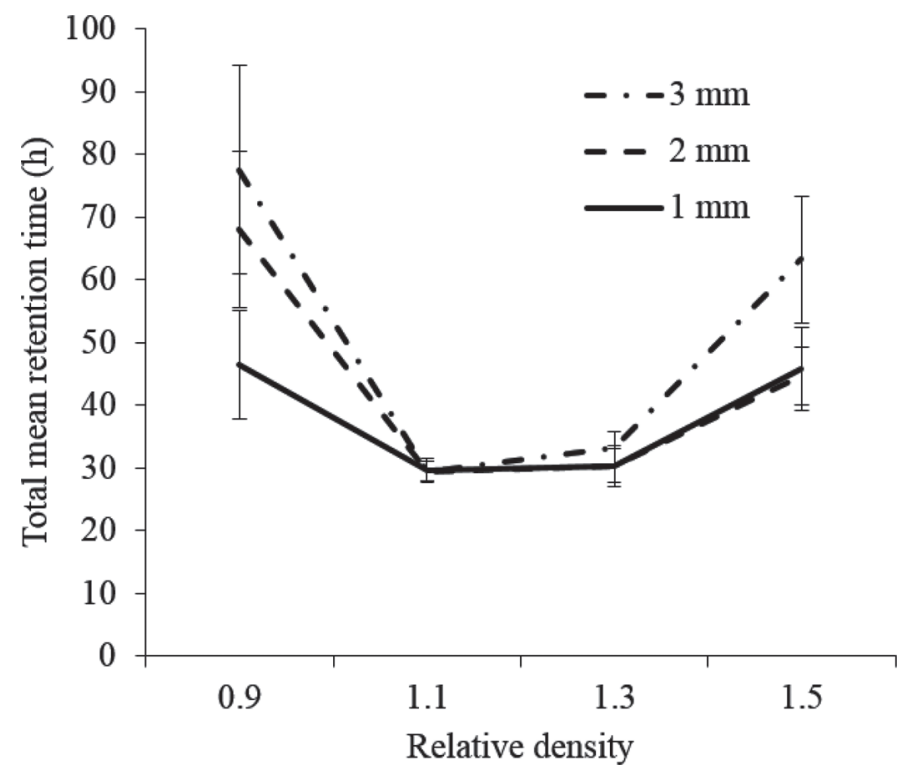

Figure 2. Influence of relative density (0.9-1.5) and diameter (1-3 $\mathrm{mm}$ ) on total mean retention time in the entire digestive tract. 
3 -mm particles in the same range of density $(81.9 \%$, Table 2). This indicates that our innovative method for image analysis is effective for counting particles.

Recovery rates in our study for 2 - and 3-mm particles were lower for densities 0.9 and 1.5 (30.0 and 68.6\%, respectively) than for densities 1.1 and 1.3 (90.2 and $73.6 \%$, respectively; Table 2). This agrees with data from the literature, which also observed lower recovery rates for particles with a density lower than 1.0 (average of the studies: 17.7\%; Figure 4) or higher than 1.5 (average of the studies: $46.7 \%$ ). This low recovery rates for 2- and 3-mm particles may be related to the increase in TMRT (Figure 5) rather than a problem with the method. The low recovery rate for particles of density 0.9 may indicate that this density is too low for sedimentation to occur in the rumen and for particles to pass out of the rumen through the reticulo-omasal orifice, as observed by Campling and Freer (1962), DesBordes and Welch (1984), Ehle and Stern (1986), and Welch (1990). Those authors observed slow and uniform excretion of particles with densities lower than 1.0 when feces were sampled $10 \mathrm{~d}$ after the particles were inserted into the rumen. The period over which feces were collected may explain these low rates of particle recovery. Similar to other studies using plastic particles (King and Moore, 1957; Kaske et al., 1992) or concentrates with lactating cows (Mambrini and Peyraud, 1997; Zebeli et al., 2007; Krämer et al., 2013), our collection period lasted $106 \mathrm{~h}$; however, a longer collection period might have increased the particle recovery rate. The longer periods reported in the literature (mean

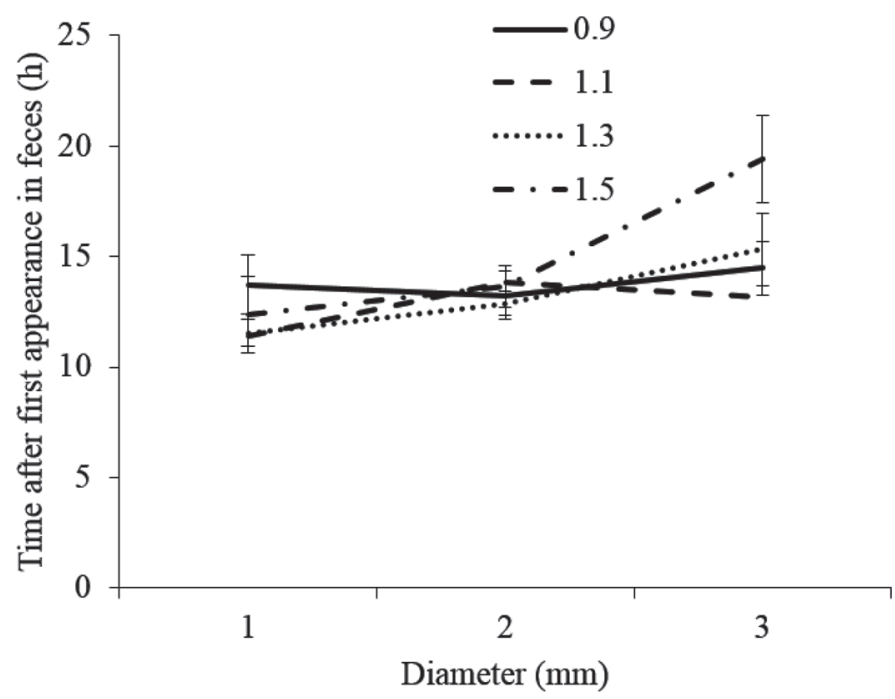

Figure 3. Influence of relative density (0.9-1.5) and diameter (1-3 $\mathrm{mm}$ ) of plastic particles on the time until they first appear in the feces, according to the model of Grovum and Williams (1973), equivalent to mean retention time in the intestines' tubular section (Mambrini and Peyraud, 1997).
8.3 d; Welch and Smith, 1978; Welch, 1982; DesBordes and Welch, 1984; Ehle and Stern, 1986; Murphy et al., 1989; Kaske and Engelhardt, 1990; Prigge et al., 1990; Clauss et al., 2011) did not facilitate complete recovery of particles of low or high density. In our study, the experimental design and collection of particles in different sieves based on their size avoided confounding particles from a given period if they were still being excreted during the subsequent period. Nevertheless, these low recovery rates might have induced an underestimation of the MRT, as all particles have not been recovered (i.e., some particles were still in the digestive tract with, therefore, a longer MRT) but relative MRT between size-density combinations still indicate those that escape the rumen the fastest.

The recovery rate of $1-\mathrm{mm}$ particles with densities of 1.1 to 1.5 was 30 percentage points lower in our study than in other studies (King and Moore, 1957; DesBordes and Welch, 1984; Ehle and Stern, 1986; Murphy et al., 1989), and we observed no linear relationship between the particle recovery rate and TMRT as we did for the 2 other sizes $\left(R^{2}=0.08\right.$; Figure 5$)$. This indicates that the low recovery rate of $1-\mathrm{mm}$ particles might have resulted from a problem with the method, as these particles displayed static electricity when sieved. Consequently, they could have clung to fecal residues during water separation despite the surfactant used to avoid this problem. In contrast, the 2- and 3-mm particles were likely large enough to overcome static electricity during water separation. Thus, results for 1-mm particles must be taken with more caution than the others, despite the consistent results.

Finally, based on observations during the first period of our trial, we decided not to distinguish ruminated and nonruminated particles, as the proportion of ruminated particles was very low during this period. For the same reason, the number of particles reduced by rumination (i.e., particles passing through their recovering sieve) have not been recorded. However, other studies (DesBordes and Welch, 1984; Murphy et al., 1989; Clauss et al., 2011; Lauper et al., 2013) have reported high proportion of ruminated particles. We assumed that our low proportion of ruminated particles might be linked to higher DMI of our animals compared with literature. Nevertheless, it cannot be precluded that the nonseparation of ruminated and nonruminated particles might have influenced our MRT.

\section{Influence of DMI on TMRT of Plastic Particles}

In our study, the TMRT of plastic particles of densities 0.9 to 1.3 was much shorter $(44 \mathrm{~h})$ than reported in previous studies (76.3 h; Figure 6). Voluntary DMI was much higher in our study, which used high-producing 


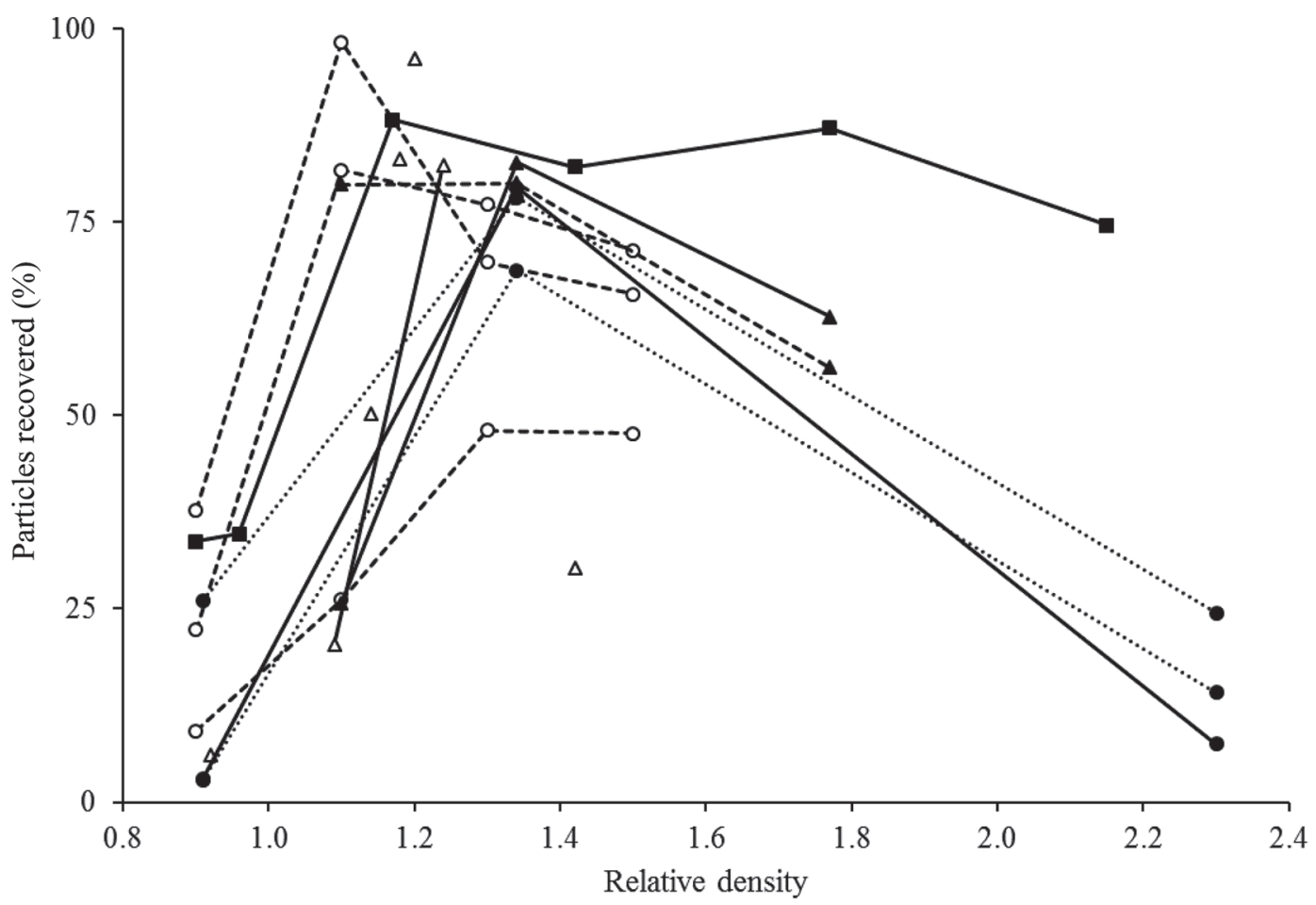

Figure 4. Influence of the relative density of plastic particles on the percentage of particles recovered from the digestive tract of cattle. Lines connect particles with the same size in a given experiment (hatched lines $=$ particles size $\leq 3 \mathrm{~mm}$; solid lines $=$ particles size between 3 and 5 $\mathrm{mm}$; dotted lines = particles size $>5 \mathrm{~mm}) . \boldsymbol{\square}=$ DesBordes and Welch (1984); $\bullet=$ Ehle and Stern $(1986) ; \Delta=$ King and Moore $(1957) ; \boldsymbol{\Delta}=$ Murphy et al. (1989); $\bigcirc=$ present study.

dairy cows $\left(157 \mathrm{~g}\right.$ of $\mathrm{DM} / \mathrm{kg}$ of $\left.\mathrm{BW}^{0.75}\right)$ than in the previous studies conducted with dry cows, steers, or sheep on maintenance diets (mean $84 \mathrm{~g}$ of $\mathrm{DMI} / \mathrm{kg}$ of $\mathrm{BW}^{0.75}$; Welch and Smith, 1978; Ehle and Stern, 1986;

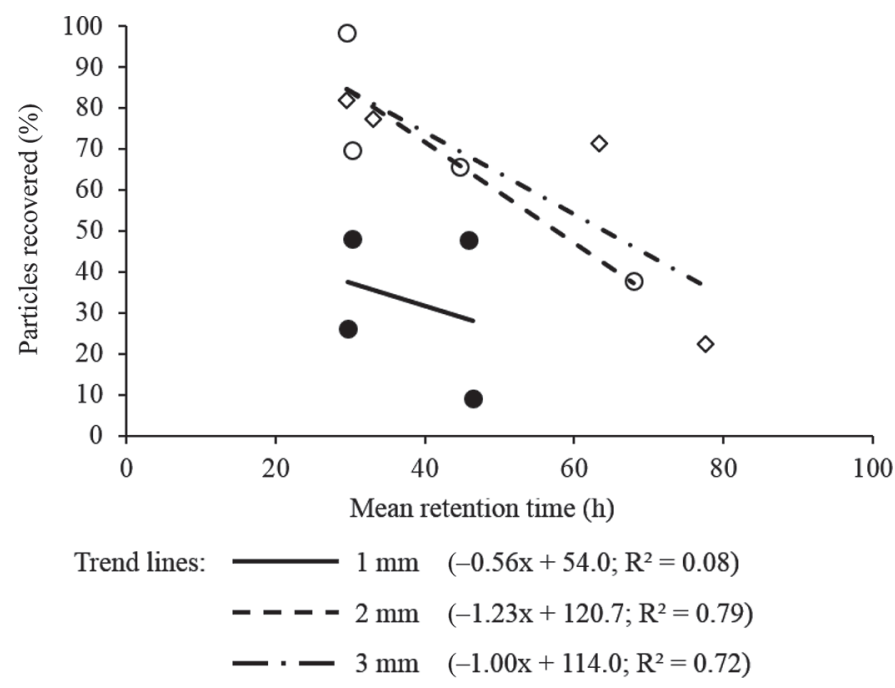

Figure 5. Percentage of particles recovered as a function of their mean retention time $(\mathrm{h})$ in the digestive tract for the size $1(\bullet), 2$ $(\bigcirc)$, and $3 \mathrm{~mm}(\diamond)$. Each dot represents the mean for all 4 cows for a particle size-density combination.
Kaske and Engelhardt, 1990; Prigge et al., 1990; Clauss et al., 2011). It is well established that the TMRT of forage particles decreases as DMI increases (Colucci et al., 1982; Shaver et al., 1986). We observed the same relation for the MRT1 of plastic particles, with shorter MRT than those of other studies due to higher DMI (Figure 7). Allen (1996) also reported that an increase in voluntary DMI decreased MRT in the reticulo-rumen, probably through specific mechanisms that control flow through the reticulo-omasal orifice. Consequently, the restriction on feed intake (95\% of DMI) may have resulted in a slight increase of the TMRT but because the restriction applied was not severe, the effect on TMRT must be minimal.

\section{Influence of Density on the MRT of Plastic Particles}

The TMRT was shortest for densities 1.1 to 1.3 and sharply increased for densities 0.9 and 1.5. This response curve agrees with data from the literature, for which the shortest TMRT were generally observed for particles of densities 1.1 to 1.4 (Figure 6). King and Moore (1957) observed the shortest MRT for particles of density 1.24, whereas Campling and Freer (1962) observed that TMRT increased for particle densities of 1.4 or more. DesBordes and Welch (1984) observed the 


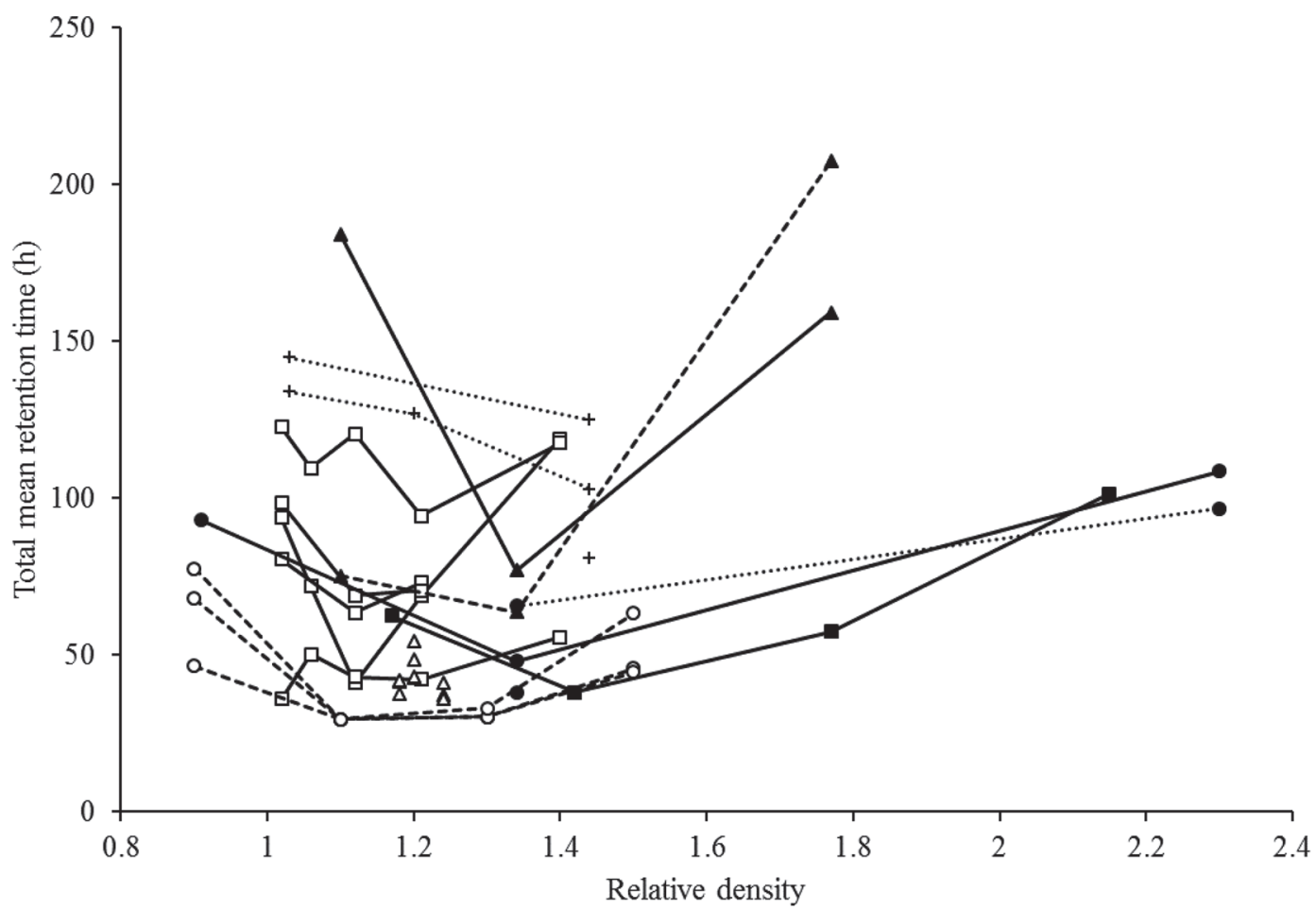

Figure 6. Influence of the relative density of plastic particles on the total mean retention time in cattle. Lines connect particles with the same size in a given experiment (hatched lines $=$ particles size $\leq 3 \mathrm{~mm}$; solid lines $=$ particles size between 3 and $5 \mathrm{~mm}$; dotted lines $=$ particles size $>5 \mathrm{~mm}$ ). Note: We calculated total mean retention time for the studies of DesBordes and Welch (1984) and Murphy et al. (1989) by adjusting their cumulative percentage of particles recovered with the model of Grovum and Williams (1973). $\square=$ Campling and Feer (1962); + = Clauss et al. (2011); $\boldsymbol{\square}=$ DesBordes and Welch (1984); $\boldsymbol{\bullet}=$ Ehle and Stern (1986); $\Delta=$ King and Moore (1957); $\boldsymbol{\Delta}=$ Murphy et al. (1989); $\mathrm{O}=$ present study.

shortest MRT for particles of density 1.42 and TMRT increasing moderately from densities 1.4 to 1.7 and more rapidly from 1.7 to 2.15 .

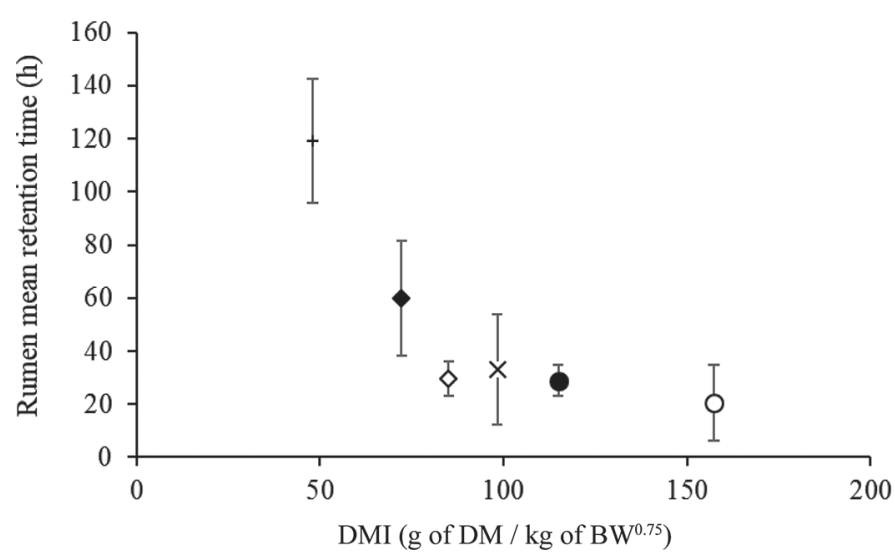

Figure 7. Rumen mean retention time of plastic particles as a function of DMI of animals on maintenance diets $(\diamond, \diamond, \bullet$, and $\times$ ) and lactating cows $(\bigcirc)$. Each dot represents the mean of rumen mean retention time for particles of all sizes and densities tested in each study. $\bullet=$ Ehle and Stern (1986); + = Clauss et al. (2011); $\bullet=$ Kaske and Englhart (1990); $\times=$ Prigge et al. (1990); $\diamond=$ Welch and Smith (1978); $\bigcirc=$ present study.
As for TMTR, MRT1 was shortest for densities 1.1 and 1.3 and increased for densities 0.9 and 1.5. This is consistent with Ehle and Stern (1986), Kaske and Engelhardt (1990), and Murphy et al. (1989), who reported minimum MRT in the entire digestive tract and the rumen for the same range of densities (1.34, 1.44 , and 1.34 , respectively). Therefore, it appears that particles with densities ranging from 1.1 to 1.4 have the shortest MRT in the rumen. Particles with a density higher than 1.4 or 1.5 probably separate from the rumen fiber mat better than particles with a lower density, but they are not readily transported with liquids once they are in the ventral section of the rumen, which could explain the longer MRT, as Campling and Freer (1962) suggested. A density of 1.0 or lower is too low to allow sedimentation from the rumen fiber mat and, thus, passage of particles out of the rumen.

\section{Influence of Particle Size on the MRT of Plastic Particles}

The influence of particle size on TMRT is consistent with results of other studies, where increasing the size of particles increases MRT (Campling and Freer, 1962; 
Welch and Smith, 1978; Welch, 1982; Ehle and Stern, 1986; Kaske and Engelhardt, 1990; Clauss et al., 2011). From a meta-analysis of literature data, Lechner-Doll et al. (1991) demonstrated an exponential response curve for TMRT as particle size increases from 1 to $20 \mathrm{~mm}$. In our study, TMRT had a linear response to particle size; however, we tested a smaller range of sizes that is consistent with that of concentrate particles. Therefore, the shape of the response does not necessarily contradict those of other studies.

Prigge et al. (1990) found that MRT in the rumen increased for nylon particles with diameters larger than $3 \mathrm{~mm}(19.3,20.3$, and $60.1 \mathrm{~h}$ for 1,3 , and $5 \mathrm{~mm}$, respectively), which is consistent with our results. The critical size threshold theory, first suggested by Poppi et al. (1980), established a threshold of 3 to $4 \mathrm{~mm}$ for cattle, although it may vary with the level of intake and the type of diet (Van Soest et al., 1986). In our study, particle size was smaller than the critical size, and the intake levels were high; thus, the lack of effect of particle size on MRT1 was not surprising.

We observed a linear increase in TT as particle size increased. Ehle and Stern (1986) and Siciliano-Jones and Murphy (1986) reported that particle size had no influence on TT [average $16.3 \mathrm{~h}(\mathrm{SD}=1.3)$ for density 1.34 and $31.5 \mathrm{~h}(\mathrm{SD}=4.2)$ for density 2.3; Ehle and Stern, 1986] for diameters of 3 to $12 \mathrm{~mm}$, which indicates that particles smaller than $3 \mathrm{~mm}$ might transit the tubular section of the digestive tract faster. More studies are required to confirm this hypothesis; however, the influence of TT on TMRT remained smaller than that of MRT1.

\section{Overall Response of MRT to the Size and Density of Plastic Particles}

Our experiment was designed to study the interaction between particle size and density on MRT. Two interactions were detected. Particle size appears to have little effect on TMRT and MRT1 when particle density is 1.1 to 1.3. For particle densities outside of this range, the smaller the size, the shorter are the TMRT and MRT1. Murphy et al. (1989) performed an experiment with similar range of size $(2-5 \mathrm{~mm})$ and density $(1.1,1.34$, and 1.77), which was in part consistent with ours, with size appearing to have less effect on rumen MRT for density 1.34 than for the 2 other densities (1.1 and 1.77). For densities 1.1 and 1.77 , the influence of size is not as clear as in our study, as particles of size $2 \mathrm{~mm}$ had shorter MRT than 5 $\mathrm{mm}$ for density 1.1 but reversed order for density 1.77 . However, Murphy et al. (1989) used an experimental diet based on $95 \%$ of rice straw, which cannot be used to feed lactating cows with high requirements, as rice straw is low digestibility feed; thus, comparison between the study of Murphy et al. (1989) and ours must be taken with caution, as they refer to very different experimental conditions.

The TT increased as particle size and density increase, and the larger and denser the particle, the longer the TT. As mentioned, few studies have focused on the influence of the size of plastic particles on TT (Ehle and Stern, 1986; Siciliano-Jones and Murphy, 1986). These studies observed no size effect but did observe a density effect consistent with our results: particles of density 1.0 were retained an average of 18 to $19 \mathrm{~h}$, and denser particles were retained 3 to $8 \mathrm{~h}$ longer (Kaske and Engelhardt, 1990).

\section{Application to Feed Particles}

Movement of a feed particle in the rumen and its passage through the reticulo-omasal orifice depends on processes such as mastication, hydration, comminution, colonization, and degradation. As time passes, the particle can pass more easily as some of its characteristics change, such as size, moisture content, and functional specific gravity (FSG). Retention time of feed particles in the rumen also depends strongly on fermentation and degradation, which are the factors that influence dynamics of the FSG of feed particles the most among the factors that influence their buoyancy (Lechner-Doll et al., 1991). First, fermentation produces gases on particle surfaces, which in turn decreases particle density (Hooper and Welch, 1985; Sutherland, 1986; LechnerDoll et al., 1991; Wattiaux et al., 1992). Then, once degradation ends, a particle's FSG increases again as gas content decreases and the proportion of its higherdensity components increases. Wattiaux et al. (1992) observed in vitro a decrease in FSG from 1.12 at $3 \mathrm{~h}$ after incubation to 1.05 at $9 \mathrm{~h}$ for alfalfa hay due to fermentation gases, and then an increase up to 1.31 at $30 \mathrm{~h}$ when the gases were released.

Plastic particles are biologically inert. Their original size and density tend to remain constant regardless of their MRT; thus, their dynamics do not accurately represent how feed particles pass through the rumen. However, accurate description of MRT response curves, by testing the ranges of size and density generally observed for particles in the rumen, enabled us to identify characteristics required for particles to leave the rumen as quickly as possible to limit their degradation. Because the FSG of concentrates begins to decrease once they arrive in the rumen, the closer that particle density is to 1.3 , the more time it will take for its density to decrease to less than 1.1. Therefore, a density ranging from 1.2 to 1.3 seems to be an optimum to minimize the retention time in the rumen. 
Concerning particle size, many authors (Bjorndal et al., 1990; Michalet-Doreau and Cerneau, 1991; Wattiaux et al., 1992; Bhatti and Firkins, 1995; Wadhwa et al., 1998) have shown that degradation rate decreases as the surface-to-mass ratio of particles increases. Consequently, large particles ferment more slowly than small particles and require more time to degrade (Bjorndal et al., 1990). They can escape the rumen less degraded than smaller particles, provided their MRT is not too long. A particle with a size near the critical threshold (i.e., $3 \mathrm{~mm}$ and no more than $4 \mathrm{~mm}$ ) may have a higher probability of escaping the rumen less degraded. Based on our data, we assume that a spherical concentrate particle with a FSG of 1.2 to 1.3 and a diameter of 3 to $4 \mathrm{~mm}$ will more likely leave the rumen without being greatly degraded, thus increasing the proportion of particles escaping the rumen within a given time period.

\section{CONCLUSIONS}

This study was designed to describe the combined effect of the size and density of plastic particles on MRT in different parts of the gastrointestinal tract of lactating cows and to determine the size and density combination that passed most rapidly out of the rumen. Description of response curves of MRT enabled us to determine characteristics required for concentrate particles to leave the rumen quickly, to limit their ruminal degradation, and to increase escape protein. Particles with densities of 1.2 to 1.3 had the lowest MRT in the entire digestive tract and in the rumen. Particles of 1 to $3 \mathrm{~mm}$ in diameter with this range of density had little influence on MRT. However, given the effect of particle size on the rate of ruminal degradation, a 3- to 4-mm diameter feed particle would have a higher probability of leaving the rumen less degraded. These assumptions require testing feeds subjected to microbial fermentation to assess the increase in RUP in the feed when size and density are fixed. In addition, combining these physical properties with chemical protection, which delays the rate of ruminal fermentation of protein, could be a promising strategy to further increase RUP.

\section{ACKNOWLEDGMENTS}

This study was supported by the European Union and the Regional councils of Pays de la Loire and Bretagne (France), which funded the project "DY+," carried out by the competitive cluster "Valorial." Manufacture of the plastic particles was supported by the cooperative Agrial. We thank the physiology team of Méjusseaume (P. Lamberton, D. Chevrel, P.-Y. Pennober, J.-L. Harel, J.-Y. Thebault, and J. Lassalas; Le Rheu, France) for their help with the experiment.

\section{REFERENCES}

Allen, M. S. 1996. Physical constraints on voluntary intake of forages by ruminants. J. Anim. Sci. 74:3063-3075.

Barry, T. N. 1976. The effectiveness of formaldehyde treatment in protecting dietary protein from rumen microbial degradation. Proc. Nutr. Soc. 35:221-229.

Bayourthe, C., and D. Ali-Haimoud-Lekhal. 2014. Les extraits de plantes chez le ruminant: effets sur les fermentations dans le rumen et la qualité lipidique des produits animaux. INRA Prod. Anim. $27: 317-328$.

Bhatti, S. A., and J. L. Firkins. 1995. Kinetics of hydration and functional specific gravity of fibrous feed by-products. J. Anim. Sci. $73: 1449-1458$.

Bjorndal, K. A., A. B. Bolten, and J. E. Moore. 1990. Digestive fermentation in herbivores: Effect of food particle size. Physiol. Zool. 63:710-721.

Broderick, G. A., R. J. Wallace, and E. R. Orskov. 1991. Control of Rate and Extent of Protein Degradation. T. Tsuda, Y. Sasaki, and R. Kawasima, ed. Academic Press, San Diego, CA.

Campling, R. C., and M. Freer. 1962. The effect of specific gravity and size on the mean time of retention of inert particles in the alimentary tract of the cow. Br. J. Nutr. 16:507-518.

Clauss, M., I. Lechner, P. Barboza, W. Collins, T. A. Tervoort, K.-H. Südekum, D. Codron, and J. Hummel. 2011. The effect of size and density on the mean retention time of particles in the reticulorumen of cattle (Bos primigenius f. taurus), muskoxen (Ovibos moschatus) and moose (Alces alces). Br. J. Nutr. 105:634-644. https:/ /doi.org/10.1017/S0007114510004101.

Colucci, P. E., L. E. Chase, and P. J. V. Soest. 1982. Feed intake, apparent diet digestibility, and rate of particulate passage in dairy cattle. J. Dairy Sci. 65:1445-1456. https://doi.org/10.3168/jds .S0022-0302(82)82367-9.

DesBordes, C. K., and J. G. Welch. 1984. Influence of specific gravity on rumination and passage of indigestible particles. J. Anim. Sci. 59:470-475.

Ehle, F. R., and M. D. Stern. 1986. Influence of particle size and density on particulate passage through alimentary tract of Holstein heifers. J. Dairy Sci. 69:564-568. https://doi.org/10.3168/jds .S0022-0302(86)80439-8.

Ellis, W. C. 1978. Determinants of grazed forage intake and digestibility. J. Dairy Sci. 61:1828-1840.

Grovum, W. L., and V. J. Williams. 1973. Rate of passage of digesta in sheep: 3. Differential rates of passage of water and dry matter from the reticulo-rumen, abomasum and caecum and proximal colon. Br. J. Nutr. 30:231-240.

Hooper, A. P., and J. G. Welch. 1985. Effects of particle size and forage composition on functional specific gravity. J. Dairy Sci. 68:11811188. https://doi.org/10.3168/jds.S0022-0302(85)80945-0.

INRA. 2007. Alimentation Des Bovins, Ovins et Caprins. Besoins Des Animaux - Valeurs Des Aliments. Editions Quae, Versaille, France.

Kaske, M., and W. V. Engelhardt. 1990. The effect of size and density on mean retention time of particles in the gastrointestinal tract of sheep. Br. J. Nutr. 63:457-465.

Kaske, M., S. Hatiboglu, and W. V. Engelhardt. 1992. The influence of density and size of particles on rumination and passage from the reticulo-rumen of sheep. Br. J. Nutr. 67:235. https://doi.org/ 10.1079/BJN19920027.

King, K. W., and W. E. C. Moore. 1957. Density and size as factors affecting passage rate of ingesta in the bovine and human digestive tracts. J. Dairy Sci. 40:528-536. https://doi.org/10.3168/jds .S0022-0302(57)94516-2.

Krämer, M., P. Lund, and M. R. Weisbjerg. 2013. Rumen passage kinetics of forage- and concentrate-derived fiber in dairy cows. J. Dairy Sci. 96:3163-3176. https://doi.org/10.3168/jds.2012-6146.

Krizsan, S. J., H. Gidlund, F. Fatehi, and P. Huhtanen. 2017. Effect of dietary supplementation with heat-treated canola meal on ruminal nutrient metabolism in lactating dairy cows. J. Dairy Sci. 100:8004-8017. https://doi.org/10.3168/jds.2017-12625.

Lauper, M., I. Lechner, P. S. Barboza, W. B. Collins, J. Hummel, D. Codron, and M. Clauss. 2013. Rumination of different-sized par- 
ticles in muskoxen (Ovibos moschatus) and moose (Alces alces) on grass and browse diets, and implications for rumination in different ruminant feeding types. Mamm. Biol. 78:142-152. https://doi .org/10.1016/j.mambio.2012.06.001.

Lechner-Doll, M., M. Kaske, and W. V. Engelhardt. 1991. Factors affecting the mean retention time of particles in the forestomach of ruminants and camelids. Pages 455-482 in Physiological Aspects of Digestion and Metabolism in Ruminants. T. Tsuda, Y. Sasaki and R. Kawasima, ed. Academic Press, San Diego, CA.

Mambrini, M. 1990. Etude du temps de séjour des résidus alimentaires dans le tube digestif des vaches laitières: Aspects méthodologiques et facteurs de variation. Sciences Biologiques Thesis. Université de Rennes, Rennes, France.

Mambrini, M., and J. L. Peyraud. 1997. Retention time of feed particles and liquids in the stomachs and intestines of dairy cows. Direct measurement and calculations based on faecal collection. Reprod. Nutr. Dev. 37:427-442.

Mambrini, M., J. L. Peyraud, H. Hetault, A. Stephant, and M. Texier. 1994. Mean retention time in digestive tract and digestion of fresh perennial ryegrass by lactating dairy cows: Influence of grass maturity and comparison with a maize silage diet. Reprod. Nutr. Dev. 34:9-23.

Michalet-Doreau, B., and P. Cerneau. 1991. Influence of foodstuff particle size on in situ degradation of nitrogen in the rumen. Anim. Feed Sci. Technol. 35:69-81. https://doi.org/10.1016/0377 -8401(91)90100-7.

Min, B., T. Barry, G. Attwood, and W. McNabb. 2003. The effect of condensed tannins on the nutrition and health of ruminants fed fresh temperate forages: A review. Anim. Feed Sci. Technol. 106:3-19. https://doi.org/10.1016/S0377-8401(03)00041-5.

Murphy, M. R., P. M. Kennedy, and J. G. Welch. 1989. Passage and rumination of inert particles varying in size and specific gravity as determined from analysis of faecal appearance using multicompartment models. Br. J. Nutr. 62:487-492.

Poppi, D. P., B. W. Norton, D. J. Minson, and R. E. Hendricksen. 1980. The validity of the critical size theory for particles leaving the rumen. J. Agric. Sci. 94:275-280. https://doi.org/10.1017/ S0021859600028859.

Prigge, E. C., B. A. Stuthers, and N. A. Jacquemet. 1990. Influence of forage diets on ruminal particle size, passage of digesta, feed intake and digestibility by steers. J. Anim. Sci. 68:4352-4360.

Shaver, R. D., A. J. Nytes, L. D. Satter, and N. A. Jorgensen. 1986. Influence of amount of feed intake and forage physical form on digestion and passage of prebloom alfalfa hay in dairy cows. J. Dairy Sci. 69:1545-1559. https://doi.org/10.3168/jds.S0022 -0302(86)80571-9.

Sherrod, L. B., and A. D. Tillman. 1964. Further studies on the effects of different processing temperatures on the utilization of solventextracted cottonseed protein by sheep. J. Anim. Sci. 23:510-516. https://doi.org/10.2527/jas1964.232510x.
Siciliano-Jones, J., and M. R. Murphy. 1986. Passage of inert particles varying in length and specific gravity through the postruminal digestive tract of steers. J. Dairy Sci. 69:2304-2311.

Sutherland, T. M. 1986. Particle separation in the forestomachs of sheep. Pages 43-73 in Aspects of Digestive Physiology in Ruminants. A. Dobson and M.J. Dobson, ed. Comstock Publishing Associates. Ithaca, NY.

Van Soest, P. J., C. J. Sniffen, and M. S. Allen. 1986. Rumen dynamics. Pages 21-42 in Aspects of Digestive Physiology in Ruminants. A. Dobson and M.J. Dobson, ed. Comstock Publishing Associates. Ithaca, NY.

Vérité, R., M. Journet, J. Flechet, R. Lefaivre, B. Marquis, and M. Vérité. 1977. Utilisation des tourteaux traités au formol par les vaches laitières. II. - Effets sur la production laitière du traitement des tourteaux et du niveau d'apport azoté au début de la lactation. Ann. Zootech. 26:183-205.

Verite, R., B. Michalet-Doreau, P. Chapoutot, J. L. Peyraud, and C. Poncet. 1987. Révision du système des Protéines Digestibles dans l'Intestin (P.D.I.). Bull. Tech. INRA 70:19-34.

Wadhwa, M., D. Paul, P. Kataria, and M. P. S. Bakshi. 1998. Effect of particle size of corn grains on the release of nutrients and in sacco degradability. Anim. Feed Sci. Technol. 72:11-17. https://doi.org/ 10.1016/S0377-8401(97)00185-5.

Waghorn, G. 2008. Beneficial and detrimental effects of dietary condensed tannins for sustainable sheep and goat production-Progress and challenges. Anim. Feed Sci. Technol. 147:116-139. https:/ /doi.org/10.1016/j.anifeedsci.2007.09.013.

Wattiaux, M. A., L. D. Satter, and D. R. Mertens. 1992. Effect of microbial fermentation on functional specific gravity of small forage particles. J. Anim. Sci. 70:1262-1270.

Wattiaux, M. A., L. D. Satter, and D. R. Mertens. 1993. Factors affecting volume and specific gravity measurements of neutral detergent fiber and forage particles. J. Dairy Sci. 76:1978-1988. https:/ /doi.org/10.3168/jds.S0022-0302(93)77531-1.

Welch, J. G. 1982. Rumination, particle size and passage from the rumen. J. Anim. Sci. 54:885-894. https://doi.org/10.2134/jas1982 $.544885 \mathrm{x}$.

Welch, J. G. 1990. Inert plastics as indicators of physiological processes in the gastrointestinal tract of ruminants. J. Anim. Sci. 68:2930-2935.

Welch, J. G., and A. M. Smith. 1978. Particle sizes passed from rumen. J. Anim. Sci. 46:309-312. https://doi.org/10.2134/jas1978 .461309x.

Whitelaw, F. G., T. R. Preston, and G. S. Dawson. 1961. The nutrition of the early-weaned calf. II. A comparison of commercial groundnut meal, heat-treated groundnut meal and fish meal as the major protein source in the diet. Anim. Prod. 3:127-133.

Zebeli, Q., M. Tafaj, I. Weber, J. Dijkstra, H. Steingass, and W. Drochner. 2007. Effects of varying dietary forage particle size in two concentrate levels on chewing activity, ruminal mat characteristics, and passage in dairy cows. J. Dairy Sci. 90:1929-1942. https://doi . org $/ 10.3168 /$ jds.2006-354.

\section{APPENDIX}

Table A1. Mean retention times (MRT, h) in the entire digestive tract and its 3 compartments (MRT1, MRT2, and TT) for the 3 sizes (1, 2, and $3 \mathrm{~mm})$ and 4 densities $(0.9,1.1,1.3$, and 1.5$)$ of plastic particles

\begin{tabular}{|c|c|c|c|c|c|c|c|c|c|c|c|c|c|}
\hline $\mathrm{MRT}^{1}(\mathrm{~h})$ & 0.9 & 1.1 & 1.3 & 1.5 & 0.9 & 1.1 & 1.3 & 1.5 & 0.9 & 1.1 & 1.3 & 1.5 & SEM \\
\hline MRT1 & 24.5 & 9.5 & 10.6 & 19.2 & 43.6 & 8.9 & 9.9 & 20.2 & 50.7 & 8.3 & 11.0 & 28.4 & 9.0 \\
\hline MRT2 & 8.2 & 8.7 & 8.2 & 14.2 & 11.1 & 6.8 & 7.5 & 10.8 & 12.4 & 8.0 & 6.8 & 15.5 & 2.9 \\
\hline $\mathrm{TT}$ & 13.7 & 11.4 & 11.5 & 12.4 & 13.2 & 13.8 & 12.9 & 13.6 & 14.5 & 13.2 & 15.3 & 19.4 & 1.5 \\
\hline
\end{tabular}

${ }^{1} \mathrm{TMRT}=$ total MRT; MRT1 = MRT in the first compartment; MRT2 = MRT in the second compartment; TT $=$ time until plastic particles first appear in the feces. 